mology and hydrobiology. Much new material was introduced into the teaching and inevitably some of the older topics were omitted. For this Gardiner was, at times, sharply criticized by some of his colleagues in other universities, but by 1930 he had the satisfaction of knowing that his Department was the recognized centre of functional morphology in Great Britain. It received large endowments and its present laboratories are the fruit of Gardiner's endeavour.

It would be wrong to regard Gardiner's great services to zoology as the result of careful and precise planning. It was not so. It was due to the width of his scientific vision and his ability to focus his attention on essential points. He never became immersed in detail, but would follow up an idea with vigour and enthusiasm. These were the qualities he looked for in others, and if Gardiner were satisfied on these two points, no young man ever approached him in vain, however strange his project might be at first sight. He never forgot that one of the primary objects of a university is to train young men to think for themselves and not to burden their memories with factual knowledge. If an exposition of somewhat arid facts were unavoidable, Gardiner would inject a leaven of speculation which, at times, might be somewhat disconcerting - as also was his famous examination question: "Discuss any zoological problem which is of particular interest to yourself".

Not the least of Gardiner's contributions to Cambridge zoology was the development of the Balfour Library. Starting with the books bequeathed by Francis Maitland Balfour, Gardiner built it up into one of the finest zoological libraries in Britain, and it is fitting that his portrait should hang over its doorway.

Gardiner was elected a trustee of the British Museum in 1931 and a member of the Standing Commission on Museums and Galleries in 1942. For these appointments he was peculiarly well fitted, for in addition to his scientific knowledge, he had a deep sense of appreciation of water-colour painting, his own collection being of considerable interest. Gardiner's hours of leisure were spent'in his garden, in yachting or in fishing. During his later years he took relatively little part in the administrative affairs of his College or of the University. $\mathrm{He}$ belonged to a generation of scientists who regarded administration as the servant of learning. The work of a committee warranted respect in so far as it facilitated work in the laboratory and no further; if it failed in this respect it was essentially something to be laughed at or ignored. In administrative circles Gardiner's particular genius was not always readily appreciated; but any conception of Gardiner as an indifferent administrator would be false. When he was sufficiently interested in a problem, his facts were accurate and his exposition concise.

Gardiner was elected to his professorship under statutes which did not involve retirement at a specific age, but he placed himself voluntarily under an obligation to retire in 1937. After a brief holiday in Cyprus, he returned to Cambridge full of vigour and devoted himself to picking up the threads of the Sealark expedition and to re-organising sections of the Balfour Library. His health failed suddenly about two years ago.

Gardiner was a leader in the sense that he broadened the field of biological research. Above all, however, he was an outstanding personality capable of inspiring in others the enthusiasm and confidence necessary for them to tackle difficult problems however remote these might be from Gardiner's own immediate interests. Perhaps the secrets of his success were that he never grew old in mind or spirit, and never took himself or others too seriously. He derived not a little amusement by disguising the real point of a conversation to the very last moment; to earnestminded students or colleagues this was often disconcerting, but he did not do this at moments of crisis. When a situation demanded action, Gardiner was quick and effective; when help was needed Gardiner never failed to respond. $\mathrm{He}$ endeared himself not only to colleagues and assistants in the laboratory, but also to each generation of students in turn. The crayon drawing by Ronaldson which hangs in the Balfour Library reflects faithfully the spirit of a distinguished scientist and a most unselfish man.

J. GRAX.

\section{Prof. F. A. Cavenagh}

By the death of Prof. F. A. Cavenagh on April 21 the academic study of education in Great Britain has lost one of its outstanding exponents. Many generations of teachers whom he trained will also regret the passing of an inspiring leader, a wise counsellor and a firm friend.

Francis Alexander Cavenagh was born in 1884 and was educated at University College, London, of which he afterwards became a fellow. He was also a student, under Sir Percy Nunn, at what was formerly known as the London Day Training College (now the Institute of Education). In 1909 he obtained the M.A. degree with distinction in classics. He then served as a schoolmaster, first at Cheltenham Grammar School and afterwards at the recently founded King Edward VII School, Lytham. In 1912 the Lytham headmaster, Mr. Bompas Smith, went on to the University of Manchester as professor of education and two years later Cavenagh was appointed as a lecturer on his staff. Cavenagh's work at Manchester was interrupted by a period of service in the Artists' Rifles and the R.G.A., and in 1919 he acted as Area Education Officer, H.Q. London District, and as lecturer at the War Office School of Education, Oxford. In 1921 he became professor of education at University College, Swansea. He worked up the Department there, almost single-handed at times in the early days, and rapidly made his mark as one of the most distinguished professors of education in Great Britain. In 1933 Prof. Dover Wilson temporarily relinquished the chair of education at King's College, London, in order to undertake a year's fulltime research, and Cavenagh took charge of the Department there; but at the end of the year he was appointed the first professor of education at Reading, where he remained until 1937. He then returned to King's College as University professor of education.

Cavenagh's tenure of the King's College professorship coincided with a time of great national difficulty. Soon after the outbreak of war his Department was evacuated to Bristol ; but the conditions there were no less trying than in London. Cavenagh had not only to cope with the administrative problems arising from evacuation, but he also threw himself wholeheartedly into A.R.P. work; and there is little doubt that his exertions and devotion in this service undermined his health. When King's College returned to London there was still a period of flying bombs and rockets to be endured, and Cavenagh continued to give himself unsparingly until his health finally broke down. 
As an educationist Cavenagh had a wide range of interest. His philosophic outlook was early evidenced by his study of "The Ethical End of Plato's 'Theory of Ideas" which was published in 1909. His educational views were based on carefully thought-out principles ; but he was no mere theorist. He was particularly interested in adult education, a member of the council of the British Institute of Adult Education and editor of its journal. He kept closely in touch with current educational developments and problems, and his criticism was always both wise and constructive. His contributions to the "Year Book of Education" and to the Journal of Education, as well as to other educational periodicals, were scholarly, judicious and authoritative. He had, perhaps, a particular interest in nineteenth-century English education, and this is evidenced by his admirable editions of the educational writings of James and John Stuart Mill, and of Herbert Spencer. Large-hearted, understanding, sincere, he leaves a place among his colleagues and friends that will be hard to fill. H. C. BARNARD.

WE regret to announce the following deaths :

Mr. E. G. Boulenger, formerly director of the Aquarium of the Zoological Society of London, on April 30, aged fifty-seven.

Dr. S. Flexner, For.Mem.R.S., emeritus director of the Rockefeller Institute for Medical Research, New York, on May 2, aged eighty-three.

Count Hermann Keyserling, author of "The Travel Diary of a Philosopher" and works on the psychology of nations, on April 26, aged sixty-five.

General Georges Perrier, member of the Section of Geography and Navigation of the Paris Academy of Sciences, formerly general secretary of the International Union of Geodesy and Geophysics, aged seventy-three.

\section{NEWS and VIEWS}

Retirement of Dr. F. H. A. Marshall, C.B.E., F.R.S.

IN 1943 Dr. F. H. A. Marshall officially retired from the readership in agricultural physiology in the University of Cambridge on account of age, but he consented to carry on with the duties during the war period. These duties he relinquished at the beginning of 1946. By the production of his book on "The Physiology of Reproduction" in 1910, and the subsequent edition in 1922, Marshall laid the foundations for much scientific work on this subject both in Great Britain and in the United States : the discovery of the hormones of the anterior pituitary and much of the modern science of endocrinology was stimulated by the publication of his book. In addition, as reader in agricultural physiology at the School of Agriculture, Cambridge, he initiated the application of the science of physiology to the problems of animal production and has stimulated and encouraged many generations of agricultural students to study the animal and the way it works, to the great advantage of the animal-breeding industry. His work has been recognized by a number of academic distinctions and by the award of the Royal Medal of the Royal Society in 1940. It is felt, however, by many of his friends, that some more personal tribute should be paid to him on this occasion, and a fund is, therefore, being set up at the School of Agriculture, Cambridge, in order to make him a presentation, a part of which it is hoped to use for a portrait.

\section{Physical Society and the Société Française de Physique : Holweck Prize and Medal}

EarLy in 1945 Prof. E. N. da C. Andrade, then president and now foreign secretary of the Physical Society, on behalf of the Council issued to fellows and friends of the Society an appeal for contributions for the foundation of a prize as a mark of their admiration for, and sympathy with, their French colleagues who had worked strenuously under great difficulties during the German occupation, and as a memorial to Dr. Fernand Holweck, the distinguished director of research at the Institut du Radium in Paris, who had died at the hands of the Gestapo, and to other French physicists who met their deaths or suffered privation. The sum collected has enabled the Physical Society to establish a Holweck Prize, to be awarded annually for ten years alternately to a French and British physicist for distinguished work in experimental physics, the presentation to the French winners to be made in London and those to the British winners in Paris. The scheme evoked lively interest and profound gratitude in French circles, and the Société Française de Physique, with which intimate co-operation in the selection for the Prize has been sought, has founded a Holweck Medal which is to be presented to each recipient of the Holweck Prize.

The first award of the Holweck Prize has been made to Prof. Charles Sadron, of the Institute of Physics, University of Strasbourg, in recognition of his many researches, notably those on the mechanical properties of liquids. $\mathrm{He}$ is, fortunately, one of the survivors of the horrors of the ill-famed Buchenwald concentration camp. The presentation will take place at a meeting of the Physical Society at the Royal Institution on May 16, in the presence of His Excellency the French Ambassador, and the president and other distinguished representatives of the Société Française de Physique ; it will be followed by a discourse by Prof. Sadron on "Some Physical Properties of Long-chain Molecules".

\section{University Entries for 1946-47}

IN a statement made in the House of Commons on April 30, Mr. G. A. Isaacs, Minister of Labour and National Service, announced the conditions which are to govern entry of students to universities in Britain for the year beginning October 1946. They fall into three sections: preference will be given to those who have served in the Armed Forces or in civilian work of national importance ; places in all subjects are to be filled; and those granted deferment from military service will be called up on the completion of their university courses. Universities can apply for release from the Forces of scholars and highly promising students in release groups 1-55, and they may also admit students who have completed three years of national service; the latter will be granted continued deferment to enable them 